\title{
Dilemmas of Feminist Practice in Transnational Spaces: Solidarity, Personal Growth, and Potential Solutions
}

\author{
Hamsa Rajan and Kerrie Thornhill
}

\section{Introduction}

A rich body of scholarly literature makes clear that the dilemmas of transnational feminist research, practice, and solidarity are extensive, fraught with dangers and potential unintended negative consequences. Tendencies of outsiders to stereotype or essentialise underprivileged groups, even unwittingly, often lead to paternalistic attitudes, resulting at times in resentment or even damage to marginalised communities (Abu-Lhugod, 2013; Amadiume, 1997; Hesford \& Kozol, 2005; Smith, 2011; Stone-Mediatore, 2009; Ticktin, 2011). As we have written elsewhere, for example, insufficiently examined assumptions can lead to NGO complicity in upholding or strengthening patriarchy (Thornhill, 2012), while condescending or silencing attitudes towards the 'other' can lead to 'policies by which asylum seekers are only granted asylum if their personal histories help to further the Northern state's narrative of itself as superior to the global South' (Rajan, 2018, p. 270). African-American feminist bell hooks observes that "[S]peech about the "Other" is a mask, an oppressive talk hiding gaps...that space where our words would be if we were speaking,' (hooks, 1989, p. 208). A certain kind of paternalism is sometimes common, therefore, in Northern or white-dominant elitist feminist spaces, even those that make claims to intersectionality.

To respond to these dilemmas, anthropologists have explored how feminist collaboration between individuals of disparate societies should be undertaken, how authors can represent those involved in their research in an ethical manner, and the effect of researcher reflexivity and practice on the furthering of feminist political ends. More than a decade ago articles published in this journal undertook precisely these discussions (Staeheli \& Nagar, 2002), while subsequent scholarship encompasses a range of topics, such as consent, representation, 'false consciousness', and the challenges of building solidarity across divides of community and nation (Abu-Lhugod, 2013; Hesford \& Kozol, 2005; Kalev, 2004; Nagar, 2013; Phillips, 2010; Sultana, 2007).

Feminist geography in particular offers an abundance of insights for those grappling with dilemmas of transnational feminist practice. Within feminist geography, concepts such as spacialisation, scale, and geopolitics are applied to the personal-is-political foundation of gender studies; geographers have thus generated crucial insights into the nature of gendered power, with regards not only to private, personal phenomena in individuals' lives but also to more globalised structures and practices (Mott, 2016).

Our themed selection advances this cross-disciplinary conversation, attending to dilemmas of transnational solidarity in particular. It addresses the perennial challenges of solidaritybuilding across differences in wealth, power, prestige, and circumstance, furthering the discussion on how to respectfully and ethically engage in transnational feminist practice.

\section{The special issue}


Building from the existing literature, this special issue begins with the recognition of a core problem: that in the act of confronting the inequalities that stifle an egalitarian feminist engagement between the global 'South' and 'North', feminists can inadvertently reify groups, essentialising their 'culture' or 'Third World' status. While feminist critique of cultural essentialism has grown (Benhabib, 1992, 2002; Hyndman, 1998), characterisations of privilege as an obstacle to solidarity work tend to insufficiently discuss how solidarity may be enhanced, even across chasms of racial, class, national, and other forms of difference. For this themed selection, therefore, we solicited articles that explored the notion of solidarity and its possibilities in a transnational context.

In addition, while much has been written about the ethics of transnational feminist research, less has been written about how transnational feminist activism should be conducted if it is to be ethical. This includes the grey area between activism and research. We thus additionally sought to include both topics, as well as submissions, which were simultaneously both research and activist-oriented, thereby carrying forward a tradition within feminist scholarship of blurring the distinction between research and activism (Johnson, 2008; Nagar, 2013; Skinner, Hester, \& Malos, 2005). Finally, we selected papers with a view for diversity of experience, region, and positionality.

Geographically, the papers discuss movements in southern Africa, Nigeria, Jordan, Afghanistan, Pakistan, and Canada. Further, solidarity-building is explored across contexts of intergenerational change, legacies of colonial occupation, or conflicts of identity and selfrepresentation. While attempting to ethically address their own power and privilege, many of the authors simultaneously occupy racial, class, and nationality positions that leave them subject to stereotyping and scrutiny, both in the field and in Northern academia. The result is a collection which honestly grapples with the contradictions and intricacies of multi-layered positionality. It is a collection as transnational as the problems it sets out to resolve.

\section{The papers}

All of the authors contributing to this special issue work from a feminist lens that seeks to problematise easy homogenisations and stereotypes of 'Third World women'. Starting from this common foundation, the authors then delve deeper into the realities of navigating two aspects of transnational feminist practice in particular, namely the uncomfortable but at times productive circumstances that are seen when researchers occupy both an insider and outsider position in the communities they work with, and secondly, the notion of solidarity. Can solidarity ever be constructively built, across vast gulfs of experience, privilege, and worldview, and if so, how?

The articles in this themed selection reach conclusions about how best to navigate these issues, pointing to the challenges of difference, when and how these challenges may offer productive possibilities, and where some of our most important work remains to be done. As such, this issue provides a grounded analysis built on researchers' direct experience of privilege, disempowerment, and prejudice, all while striving to remain true to an anticolonial, respectful, and egalitarian ethos.

May Chazan traces the partnerships and tensions that arose between Canadian and southern African grandmothers who sought to heal communities affected by HIV/AIDS. Saba Abbas 
examines her own insider-outsider positionality over the course of her research on 'stylish' veiling in Jordan. Joyce $\mathrm{Wu}$ identifies the opportunities and challenges of engaging men to end violence against women in Afghanistan and Pakistan. Grace Adeniyi Ogunyankin explores space and place as an insider-outsider who researches urbanism in Canada and Nigeria.

One theme that emerges repeatedly in this themed selection is the accusation, faced by those who identify with feminism or implement feminist projects, that they are excessively Westernised, do not understand local problems, and hold to priorities that are irrelevant to local culture. In fact, these accusations are remarkably similar in content, despite the differing contexts of Jordan, Nigeria, Afghanistan, and Pakistan explored in this issue, suggesting the sensitivities they highlight are widespread across the globe. Indeed, as various scholars have noted, the perpetuation of patriarchy-as-tradition can be both a product of and backlash to colonial or Western intervention (Oyewumi, 2011), as neo-traditional masculinities 'are rigorously defended when cultures feel under threat from external pressures' (Fisher, 2013, p. 839).

The accusations of Westernisation and irrelevance faced by the selection's authors are simultaneously personal, political, uncomfortable, and even hurtful, particularly for those occupying simultaneous positions as insiders and outsiders in the communities they research. Ogunyankin, for example, describes the intense defensiveness displayed by many of the Nigerian participants and gatekeepers she encountered, as they repeatedly assumed she held to condescending and neo-colonial views of local people and lifestyles. One of Abbas's interviewees likewise showed irritation towards Abbas, and readily assumed that, as a feminist, Abbas must consider all veiled women in Amman to be oppressed. These researchers were judged as condescending, not because of what they said or actually believed, but simply because of their liminal position between two cultures and their identification with feminism. Informants' sensitivity and defensiveness around paternalizing narratives, deriving from histories of colonialism and their aftermath, leave insider/outsider researchers in a space which can be tricky to navigate. The authors in this themed selection describe how they managed this space, including in some cases how they learned to master the art of navigating it.

The articles in this issue additionally discuss how individuals may move towards a deeper and more nuanced awareness of power and privilege, and where some of the most important work remains to be done. In her descriptions of development work in Afghanistan and Pakistan, for example, Wu describes a conflict-ridden context fraught with grave insecurity. Yet, as Wu points out, when she analysed several international development projects aimed at reducing violence against women in this region, she found a glaring omission. Within these projects, the impacts of warfare and conflict on local gender norms and relations were left under-analysed and largely ignored. Rather than delving into the specific needs that a conflict-ridden context raises, therefore, some of these projects instead uncritically applied Western theories and procedures to this part of the world. Despite such omissions, solidarity still appears to have been built between NGO workers and local residents, as many of the latter volunteered to implement initiatives against violence against women. However, for these local volunteers, personal safety concerns and family pressures remained tricky, even treacherous, to navigate. 
Chazan also delves into the notion of transnational solidarity, particularly how it is defined and implemented by Canadian women activists working with southern African women to address the epidemic of HIV/AIDS. Chazan describes how important it is to the Canadian activists to follow a logic of solidarity, a concept they understand as involving respecting the voices and priorities of African women. Describing a rift in their activist organisation at a particular political moment in Canada, Chazan explains how an opportunity was created for the Canadian women activists to question their original, less nuanced views of power and privilege, allowing some to move towards more complex understandings of what solidarity is and should be. Some even chose to reject the term and concept altogether, seeing it as paternalistic and unnecessary.

Some authors problematise assumptions that are often found within feminist circles. Chazan, for example, argues that while a prevailing view holds that North American second wave feminists are uninterested in class and transnational power and privilege inequalities, this view may be unfair or exaggerated. Likewise, in discussing a common perception that the 'women in development' approach should be abandoned in favour of more work with men and boys, Wu argues this shift can in practice disempower women's groups and feminist agendas.

One of the most interesting facets of the articles in this themed selection lies in the details of the researchers' fieldwork interactions. The authors describe how their varying race and class positions, and the ways their positionality was perceived locally, allowed for connection and understanding in some ways, but distance and antagonism in others. The authors further depict how they navigated these spaces of both discomfort and opportunity. Often, their skills developed over the process of fieldwork such that they learned to work with these spaces in ways that became more empowering for themselves, research participants, and the theoretical and practical outcomes and applications of their research.

A final point remains to be made regarding the methodology of creating this themed selection. The editors envisioned a project that would be robustly feminist not only in its content, but also in its curation, in the voices it advocates, and in the relations and reciprocities between authors and editors. Our initial call for participation was distributed across feminist networks on every continent, with efforts to reach epistemically marginalised scholars. Every author was additionally extended the option of being put in touch with a publication mentor, if they so opted. In this way, we hope to have expanded a pathway to publication for scholars in under-resourced contexts.

This themed selection explores case studies of solidarity-building in research and action, moving towards a more resolved model of respectful and egalitarian transnational feminist practice. As a special issue steeped in the details and daily realities of fieldwork in liminal, transnational, and disparate spaces full of myriad inequalities, we hope the articles herein prove both fascinating and illuminating.

\section{References}

Abu-Lhugod, L. (2013). Do Muslim Women Need Saving? Cambridge, Massachusetts: Harvard University Press. 
Amadiume, I. (1997). Reinventing Africa: Matriarchy, religion and culture. London: Zed Books.

Benhabib, S. (1992). Situating the Self: Gender, Community and Postmodernism in Contemporary Ethics. Cambridge, UK: Polity Press.

Benhabib, S. (2002). The Claims of Culture: Equality and Diversity in the Global Era. Princeton: Princeton University Press.

Fisher, C. (2013). Changed and changing gender and family roles and domestic violence in African refugee background communities post-settlement in Perth, Australia. Violence against Women, 19(7), 833-847. https://doi.org/10.1177/1077801213497535

Hesford, W. S., \& Kozol, W. (2005). Introduction. In Just Advocacy? Women's Human Rights, Transnational Feminisms, and the Politics of Representation. New Brunswick, New Jersey: Rutgers University Press.

hooks, b. (1989). Choosing the Margin as a Space of Radical Openness. In Yearning: Race, Gender and Cultural Politics. South End Press.

Hyndman, J. (1998). Managing difference: Gender and culture in humanitarian emergencies. Gender, Place and Culture, 5(3), 241-260.

Johnson, L. (2008). Re-placing gender? Reflections on 15 years of Gender, Place and Culture. Gender, Place \& Culture, 15(6), 561-574. https://doi.org/10.1080/09663690802518412

Kalev, H. D. (2004). Cultural Rights or Human Rights : The Case of Female Genital Mutilation. Sex Roles, 51(5/6), 339-348.

Mott, C. (2016). Feminist Geography. Retrieved February 15, 2019, from http://www.oxfordbibliographies.com/view/document/obo-9780199874002/obo9780199874002-0123.xml

Nagar, R. (2013). Storytelling and co-authorship in feminist alliance work: reflections from a journey. Gender, Place \& Culture, 20(1), 1-18. https://doi.org/10.1080/0966369X.2012.731383

Oyewumi, O. (Ed.). (2011). Gender Epistemologies in Africa: Gendering Traditions, Spaces, Social Instititions, and Identities. New York: Palgrave MacMillan.

Phillips, A. (2010). Gender and Culture. Cambridge, UK: Polity Press.

Rajan, H. (2018). The Ethics of Transnational Feminist Research and Activism: An Argument for a More Comprehensive View. Signs: Journal of Women in Culture and Society, 43(2), 269-300.

Skinner, T., Hester, M., \& Malos, E. (Eds.). (2005). Researching Gender Violence: Feminist Methodology in Action. Devon: Willan Publishing.

Smith, C. (2011). Who Defines "Mutilation"? Challenging Imperialism in the Discourse of Female Genital Cutting. Feminist Formations, 23(1), 25-46. https://doi.org/10.1353/ff.2011.0009

Staeheli, L., \& Nagar, R. (2002). Feminists Talking across Worlds. Gender, Place \& Culture, 9(2), 167-172. https://doi.org/10.1080/09663960220139671 
Stone-Mediatore, S. (2009). Cross-border feminism: Shifting the terms of debate for US and European feminists. Journal of Global Ethics, 5(1), 57-71.

https://doi.org/10.1080/17449620902765310

Sultana, F. (2007). Reflexivity, Positionality and Participatory Ethics: Negotiating Fieldwork Dilemmas in International Research. ACME: An International E-Journal for Critical Geographies, 6(3), 374-385.

Thornhill, K. (2012). "You must sit on the old mat to ply the new one": rethinking threatened masculinities and post-conflict gender violence in Liberia. In J. Freedman (Ed.), Engaging Men in the Fight against Gender Violence: Case Studies from Africa. New York: Palgrave MacMillan.

Ticktin, M. (2011). In the Name of Violence against Women. In Casualties of Care: Immigration and the Politics of Humanitarianism in France (pp. 128-158). London: University of California Press. 